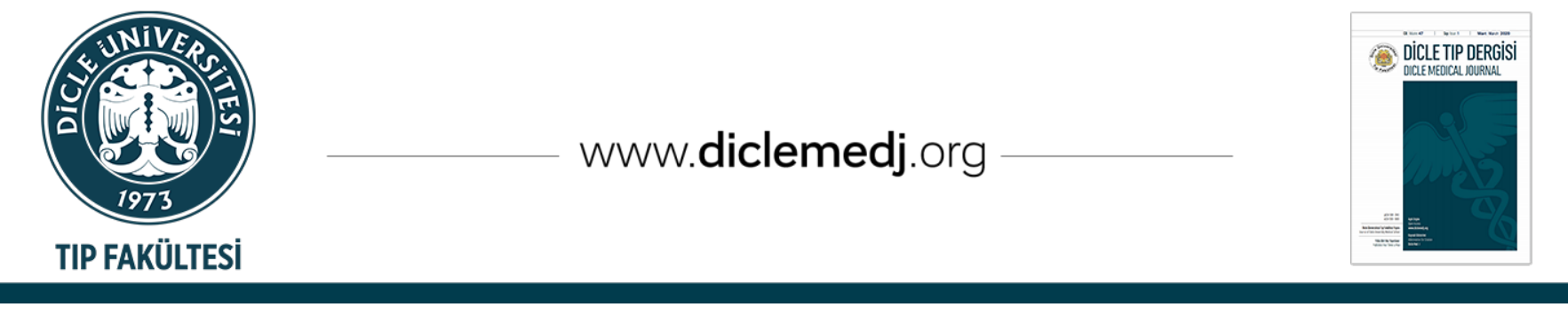

Olgu Sunumu / Case Report

\title{
MELAS AİLESİ: Klinik - Genetik Korelasyon
}

\author{
Filiz Koç ${ }^{D} 1$, Hürü Rabia Güleç ${ }^{D_{2}}$, Hakan Gelincik ${ }^{\left(D_{3}\right.}$, Atıl Bişgin $\mathrm{iD}_{4}$ \\ 1 Çukurova Üniversitesi Tıp Fakültesi, Nöroloji Anabilim Dalı, Adana, Türkiye \\ 2 Çukurova Üniversitesi Biyoteknoloji Araştırma ve Uygulama Merkezi, Adana, Türkiye \\ 3 Çukurova Üniversitesi Tıp Fakültesi, Tıbbi Genetik Anabilim Dall, Adana, Türkiye \\ 4 Başkale Toplum Sağlığı Merkezi, Van, Türkiye
}

Geliş: 14.05.2020; Revizyon: 09.07.2020; Kabul Tarihi: 17.07.2020

$\ddot{0} \mathbf{z}$

MELAS (Mitokondriyal Ensefalopati Laktik Asidoz Stroke Benzeri Epizodlar), multisistemik bir kas hastalığıdır. Klinik bulgular miyopati, göz bulguları, sensorinöral işitme kaybı, epilepsi, baş ağrısı, inme, endokrinopatiler ile prezente olur. Hastalıktan sorumlu mutasyonlar sıklık sırasına göre A3243G, T3271C, C3093G, A3252G, C3256T, A3260G, T3291C, T3308C, A13514G'dır. Bu makalede, farklı semptomlara sahip A3243G mutasyonu tespit edilen bir aileden altı MELAS'lı olgu, hastalığın klinik bulgularına dikkat çekilmek üzere sunulmuştur.

Anahtar kelimeler: MELAS, genetik, mitokondriyal DNA, klinik bulgular.

\section{MELAS FAMILY: Clinical - Genetic Correlation}

\begin{abstract}
MELAS (Mitochondrial Encephalopathy Lactic Acidosis and Stroke like episodes) is a multisystemic muscle disease. Clinical findings are presented with myopathy, eye findings, sensorineural hearing loss, epilepsy, headache, stroke, endocrinopathies. The mutations responsible for the disease are A3243G, T3271C, C3093G, A3252G, C3256T, A3260G, T3291C, T3308C, A13514G, respectively. In this article, six patients with MELAS from a family with different symptoms A3243G mutation are presented to draw attention to the clinical manifestations of the disease.
\end{abstract}

Keywords: MELAS, genetic, mitochondrial DNA, clinical findings.

DOI: 10.5798/dicletip.800322

Correspondence / Yazışma Adresi: Filiz Koç, Çukurova Üniversitesi Tıp Fakültesi Nöroloji AD- Adana, Türkiye e-mail: koc.filiz@gmail.com 


\section{GíRiş}

Mitokondriyal miyopati, Ensefalomiyopati Laktik Asidoz ve Stroke benzeri ataklar (MELAS), mitokondriyal DNA'daki (mtDNA) kalıtsal mutasyonlarla ilişkili ilerleyici bir nörodejeneratif bozukluk ve multisistemik hastalıktır. MtDNA'da (baz çiftleri 3229-3303) bulunan mitokondriyal tRNA lösin ( MT-TL1) geni, MELAS'a neden olabilecek patojenik mutasyonlar için bir hotspot bölge gibi görünmektedir ${ }^{1}$. MELAS vakalarının yaklaşık \%80'ine MT-TL1 geninin m.3243A>G mutasyonu neden olmakla birlikte, hastalıktan sorumlu 40'ın üzerinde mutasyon bildirilmiştir². Hastalığa yol açan bu mutasyonların oldukça değişken fenotipik ekspresyonu, kısmen farklı dokulardaki mutasyon yüküne (heteroplazmi) bağlıdır. Bunu biraz daha açıklayacak olursak, bilindiği gibi mitokondriyal DNA (mtDNA) nükleer DNA'dan bağımsız olarak replikasyon yapar. Mitokondrinin bu otonom özelliği, hücre bölünmesi sırasında, mtDNA'ın heteroplazmik bir dağılım göstermesini sağlar. MtDNA'da meydana gelen mutasyonlara bağlı olarak hücre içinde mutant veya normal mtDNA'ların farklı dokularda düzensiz dağılımı sonucu, hastalık aynı ailedeki farklı bireylerde bile farklı fenotiplerle karşımıza çıkabilir ${ }^{3}$. Genetik heterojenite, çeşitli klinik prezentasyon ve seyir tanıda zorluklar yaratabilir4. $\mathrm{Bu}$ makalede, oldukça çeşitli klinik semptomlara sahip bir MELAS ailesi, genotipik ve fenotipik özellikleri ile sunulmuştur.

\section{OLGU SUNUMLARI}

\section{Proband (İndeks olgu)}

Kırk üç yaşında kadın hasta, 30 yıldan bu yana göz kapaklarında düşme ve halsizlik yakınmasının olduğu bir başka sağlık kurumu tarafından olası Myastenia Gravis olarak tanındığı belirlendi. Özgeçmişinde adet düzensizliği yanı sıra diyabetes mellitus ve hipertansiyonunun olduğu oral antidiyabetik ve antihipertansif sağaltım aldığı, sensorinöral işitme kaybı nedeni ile işitme cihazı kullandığı, 8 yıl önce sol renal artere stent yerleştirildiği bildirildi. Soygeçmişinde; anne-baba akrabalığı olmadığı, beş kız kardeşinin olduğu, ailenin pek çok bireyinde işitme kaybı, halsizlik ve yorgunluk yakınmalarının bulunduğu bildirildi (Tablo 1, Şekil 1). Fizik muayenesinde: Boy $152 \mathrm{~cm}$, ağırlık $46 \mathrm{~kg}$, beden kitle indeksi 19,91 kg/m2 ve kan basıncı 128/81 mmHg olarak ölçüldü. Nörolojik muayenesinde; solda belirgin, bilateral semipitoz, oftalmoparezi (yukarı vertikal bakışta belirgin olmak üzere, 4 yöne de göz hareketleri kısıtlılığı) tespit edildi. Fundoskopik muayenesinde; makulada hiperpigmentasyon saptandı. Fasiyal dipleji ve sensorinöral işitme kaybı gözlendi. Aksiyal kas gücü $3 / 5$ düzeyinde, üst ekstremitelerde proksimal kas grupları $+4 / 5$, alt ekstremitelerde proksimal kas grupları 4/5 düzeyinde kas güçsüzlüğü (kuadriparezi) tespit edildi. Derin tendon refleksleri (DTR) hipoaktif olan hastanın, diğer sistem muayeneleri doğal sınırlarda değerlendirildi. Laboratuvar: Açlık kan şekeri 121 mg/dl (normal aralık 70-100 mg/dl) olarak ölçüldü. Tam kan sayımı, kas enzim düzeyi, karaciğer fonksiyon testleri ve hormon profilini içeren biyokimya paneli normal sınırlardaydı. Elektromyografide (EMG) motor ve duysal ileti hızları normal düzeylerdeydi. İğne EMG'de miyojenik ünit değişiklikleri gözlendi. Beyin Manyetik Rezonans Görüntüleme (MRG); bilateral perivenriküler-subkortikal beyaz cevherde T2 ve FLAIR A sekanslarda hiperintens multipl dağınık yerleşimli lezyonlar gözlendi (Resim 1). Ekokardiyografi normal olarak değerlendirildi. Odyolojik testte bilateral sensorinöral sinir etkilenmesi lehine (işitme kayıp oranı \%55) bulgular tespit edildi. Moleküler çalışmada MT-TL1 geninde mt.3243A>G mutasyonu tespit edildi ve vaka MELAS olarak tanındı.

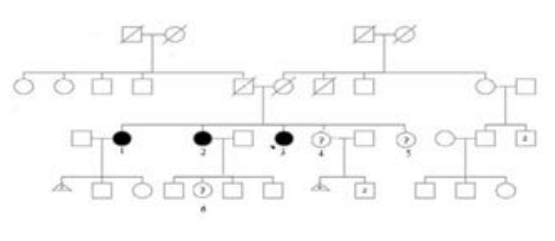

Şekil 1: Pedigri 
Tablo I: Aile bireyleri ve bulgular (Olgu no sıralaması pedigriye göre yapılmıştır).

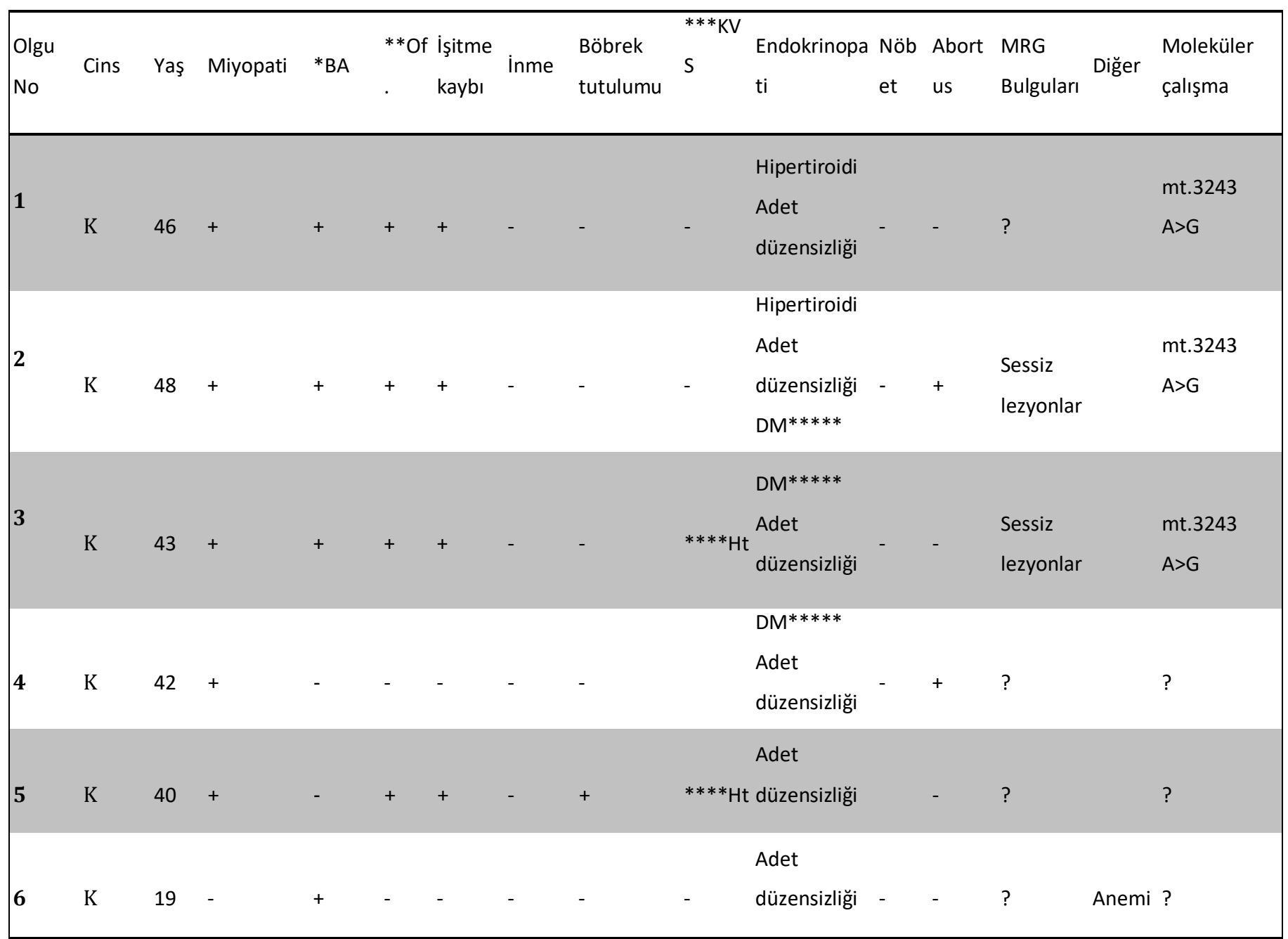

${ }^{*}$ Baş Ağrısl; ${ }^{* *}$ Oftalmoparezi; ${ }^{* * *}$ Kardiyovasküler Sistem; ${ }^{* * * *}$ Hipertansiyon; ${ }^{* * * * *}$ Diyabetes Mellitus; MRG: Manyetik Rezonans Görüntüleme; Olgu 3: Proband

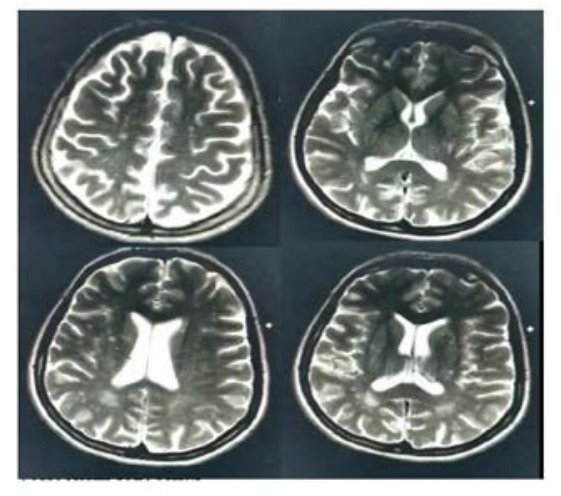

Resim 1: Periventriküler-subkortikal beyaz cevherde T2 ve FLAIR A sekanslarda hiperintens multipl dağınık yerleşimli lezyonlar alanları.

\section{Olgu 2}

Kırk sekiz yaşında kadın hasta, kız kardeşinin MELAS tanısı alması üzerine muayene olmak için kliniğe başvurdu. Öyküsünde, 20 yaşından bu yana fark ettiği halsizlik, güçsüzlük, çabuk yorulma yakınmalarının yanı sıra baş ağrılarının da olduğunu, bu nedenle migren tanısı aldığını ifade etti. Astım tanılı hastanın tiroid nodüllerinin de olduğu, hipertiroidi tanısı ile takip edildiği ve propiltiourasil kullandığı belirlendi. Evli ve dört gebelik öyküsünden ikisinin düșük ile sonuçlandığı, ilaveten gestasyonel diyabetinin de olduğu öğrenildi. İki sağlıklı çocuğu olan hastanın, böbreklerinden birini böbrek yetmezliği olan kız kardeşine 
bağışladığından, tek böbreğinin olduğu da öğrenildi. Nörolojik muayenesinde; bilateral semipitoz, oftalmoparezi, fasiyal dipleji, sensorinöral işitme kaybı olduğu tespit edildi. Aksiyal kas gücü $3 / 5$ düzeyinde olup, proksimal kas gruplarında belirgin, 4/5 düzeyinde kas güçsüzlüğü (kuadriparezi) olduğu görüldü. DTR'leri hipoaktif olan hastanın diğer sistem muayeneleri doğal sınırlarda değerlendirildi. Laboratuvar: Açlık kan şekeri $158 \mathrm{mg} / \mathrm{dl}$ (normal aralık 70-100 mg/dl) ve insülin düzeyi 35,81 $\mu \mathrm{U} / \mathrm{ml}$ (normal aralık: 1,9-23) olan hastanın; tam kan sayımı, tiroid fonksiyonları da dahil hormon profili ve biyokimya panelinin normal sinırlarda olduğu görüldü. Elektronöromiyografisinde median ve ulnar duysal ileti hizları normal olan hastada sural duysal sinir aksiyon potansiyeli elde edilemedi. Motor ileti hızlarının normal olduğu görülen hastada yapılan iğne EMG'de miyojenik ünit değişiklikleri gözlendi. Beyin MRG'de T2 sekansta hiperintens multipl dağınık yerleşimli lezyonlar gözlendi (Resim 2). Ekokardiyografi normal olarak değerlendirildi. Moleküler çalışmada MT-TL1 geninde mt.3243A $>\mathrm{G}$ mutasyonu tespit edildi ve vaka MELAS olarak tanındı. Pedigri; proband ve olgu 2'den alınan bilgiler doğrultusunda çizilmiştir. Aile bireyleri başka şehirde yaşadığından nörolojik muayeneleri yapılamamıştır. 1 numaralı olgunun moleküler çalışma sonucu MELAS lehine olduğundan, pedigride kesin vaka olarak işaretlenmiştir. 4 ve 5 numaralı olgular; güçsüzlük, göz bulguları ve sensorinöral işitme kaybının yanı sıra sistemik bulgularının da olması sebebiyle her ne kadar klinik prezentasyonlar MELAS'ı akla getirmiş olsa da, hastalar tarafımızca muayene edilmediği ve moleküler çalışmaları yapılmadığından, şüpheli MELAS olarak değerlendirilmiştir. 6 numaralı olgunun, adet düzensizliği ve aile yükünün bulunması nedeniyle, MELAS açısından değerlendirilmesi gerektiği düşünülmüştür.

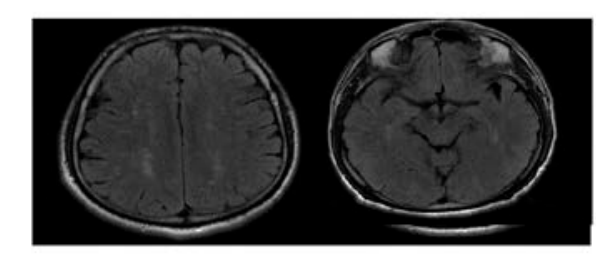

Resim 2: Periventriküler-subkortikal beyaz cevherde T2 A sekansta hiperintens multipl dağınık yerleşimli lezyonlar alanları.

\section{TARTIŞMA}

MELAS (OMIM: 540000) progresif seyirli multisistemik bir hastalık olup, prevalansı 19/1.000.000'dır. Yakınmalar, normal bir gelişim periyodunu takiben çocukluk çağlarında başlamakla birlikte, genellikle 2-40 yaşları arasında ortaya çıkar. Ancak, semptomlar her yaşta başlayabilir. Hastalık vücudun birçok sistemini, özellikle beyin, sinir sistemi ve kasları (miyopati) etkiler. Erken belirtiler arasında güçsüzlük, tekrarlayan baş ağrıları, iştah kaybı, kusma ve nöbetler yer alır. Etkilenen bireylerin çoğunda 40 yaşından önce başlayan inme benzeri ataklar görülür5. Bu ataklar genellikle yan güçsüzlüğü (hemiparezi), bilinç bozukluğu, migrenöz baş ağrıları ve görme bozukluğu ile prezente olur. Tekrarlayan inme benzeri ataklar kalıcı hasara yol açarak görme kaybı, hareket bozuklukları ve demansiyel tabloya neden olabilir. Ayrıca oftalmoparezi, işitme kaybı, endokrinopatiler, adet düzensizliği, abortus ve hipertrofik kardiyomiyopati de yakınmalara eşlik edebilirr,6-8. İndeks olgumuz; göz kapaklarında düșme, halsizlik yakınmalarından dolayı, olası Myastenia Gravis ön tanısı ile kliniğimize kabul edilmiştir. Ancak; fenotipik özellikleri, kısa boyu, kas, işitsel, endokrin ve kardiyovasküler sistemler de dahil, multisistemik tutulum bulguları, mitokondriyal sitopati olabileceğini düşündürmüștür. Tanı akabinde polikliniğe kabul edilen, indeks 
olgunun kırk sekiz yaşındaki ablasında da benzer sistemlerin etkilendiği, ayrıca 2 abortus ve astım öyküsünün olduğu dikkati çekmiştir. Proband ve olgu 2'den alınan bilgiler doğrultusunda pedigri çizilmiş ve aile bireylerine ait demografik ve sistemik tutulum bulguları Tablo 1'de özetlenmiştir. Tablo 1'de görüldüğü gibi, ailenin pek çok bireyinde işitsel, endokrin ve kardiyovasküler sistem başta olmak üzere, oldukça çeşitli klinik semptomların olduğu dikkati çekmektedir (Şekil 1, Tablo 1). Bu ailenin diğer bir ilginç özelliği ise, Tablo 1'de yer alan olguların yaşları dikkate alındığında, kırklı yaşlardan sonra tanı almalarıdır. $\mathrm{Bu}$ durum yetim hastalıklar konusunda tüm dünyada olduğu gibi, ülkemizde de farkındalığın halen yeterli düzeyde olmadığını düşündürmektedir ${ }^{9}$. Hastalık; Kearns-Sayre sendromu ve Pearson sendromu gibi mitokondriyal sitopatiler; okülofaringeal musküler distrofi ve miyotonik distrofi gibi musküler distrofiler; konjenital veya otoimmun, Myastenia Gravis gibi nöromusküler kavşak hastalıkları ile de karıştırılabilir. MELAS'ta tanı; öykü, fenotipik bulgular ve kan laktat/piruvat düzeylerini içeren laboratuvar bulgularına dayanır. İnme benzeri lezyonların varlığını göstermek için beyin MRG'nin yanı sıra, sistemik tutulumu düşündüren öykü var ise, buna yönelik incelemeler istenebilir ${ }^{10}$. MELAS'da görülen iskemik lezyonlar arter sulama alanına uymaz, bu durum klasik iskemik inmeden ayırt etmede yol göstericidir. İndeks olgumuzda ve ablasinda yapılan serebral görüntülemede sessiz lezyonlar saptanmıștır (Resim 1,2). Kas biyopsisi, tanıda kullanılabilecek diğer bir yöntem olmakla birlikte, genetik gelişmeler bu invaziv testi geri plana itmiştir. Altın standart tanı yöntemi, moleküler genetik testlerde hastalık ilişkili genlerden birinde patojenik bir varyant tespitine dayanır ${ }^{11}$. MtDNA mutasyonuna sahip bir probandın, annesi semptomsuz olabileceği gibi, göz ardı edilebilecek hafif semptomlara da sahip olabilir. Anne genellikle mtDNA patojenik varyantına sahiptir. Annede bir mtDNA patojenik varyantı tespit edilmişse, MELAS için aile taraması ve genetik danışmanlık önerilmelidir. Bugüne kadar hastalığa sebep olabilecek 40'ın üzerinde mutasyon saptanmıştır. Mitokondriyal gen MT-TL1'deki m.3243A>G patojenik varyantl, MELAS'lı kişilerin yaklaşık \%80'inde bulunur ${ }^{12}$. Bizim ailemizde de m.3243A $>\mathrm{G}$ mutasyonu saptanmıștır. Yüksek oranda A3243G mutasyonu olan kişiler ciddi işitme bozukluğu yönünden risk altındadır ${ }^{12,13}$. Fenotipik bulgular ve laboratuvar testleri MELAS'ı desteklediğinde, moleküler genetik tanı testi, tek gen üzerinden veya bir multigen paneli kullanılarak yapılabilir. Etkilenen bireylerde abortus görülebilir. Bizim ailemizde de düşük öyküleri olan bireyler bulunmaktadır. $\mathrm{Bu}$ nedenle, MELAS'lı kadınlar hamilelikten önce genetik danışmanlık almalıdır. MELAS'tan hamilelik sırasında etkilenen veya MELAS olma riski olan kadınlar, terapötik müdahaleler gerektirebilecek diyabetes mellitus ve solunum yetmezliği gelişimi açısından izlenmelidir ${ }^{11-13}$. Sonuç olarak; hastalarda bulunan mtDNA mutasyonları, hücrede oksidatif fosforilasyon sırasında enerji üretiminin azalmasına yol açar. $\mathrm{Bu}$ mutasyonlardan biri olan mt.3243A $>\mathrm{G}$ mutasyonu; ATP kaybı, laktat ve reaktif oksijen türlerinin artması dahil olmak üzere birçok biyolojik sistemi etkiler. $\mathrm{Bu}$ durum, çeşitli organların tutulmasına yol açar. Ailemizde de klinik; güçsüzlük, göz bulguları, migrenöz baş ağrıları, işitme kaybı, çeşitli endokrinopatiler ve abortus gibi multisitemik bulgular ile karakterizedir. Bu gibi çoklu semptomlar ile prezente olan hastalarda, MELAS sendromu ayırıcı tanıda yerini almalıdır.

Çalışma, 2019 yılında Adana'da düzenlenen “5. Adana Genetik Günleri Nörogenetik Sempozyumu"nda sözel bildiri olarak sunulmuştur.

Etik Kurul Kararı: Her iki olgu çalışma hakkında bilgilendirilmiş olup onam alınmıştır. 
Çıkar Çatışması Beyanı: Yazarlar çıar çatışması olmadığını bildirmişlerdir.

Finansal Destek: Bu çalışma her hangi bir fon tarafından desteklenmemiştir.

Declaration of Conflicting Interests: The authors declare that they have no conflict of interest.

Financial Disclosure: No financial support was received.

\section{KAYNAKLAR}

1. Panades-de Oliveira L, Montoya J, Emperador S, et al. A novel mutation in the mitochondrial MT-ND5 gene in a family with MELAS. The relevance of genetic analysis on targeted tissues. Mitochondrion 2020; 50: 14-8.

2. Sweeney MG, Bundey S, Brockington M, et al. Mitochondrial myopathy associated with sudden death in young adults and a novel mutation in the mitochondrial DNA leucine transfer RNA(UUR) gene. Q J Med 1993; 86: 709-13.

3. Lin J, Zhao CB, Lu JH, et al. Novel mutations m.3959G $>A$ and $m .3995 A>G$ in mitochondrial gene MT-ND1 associated with MELAS. Mitochondrial DNA 2014; 25: 56-62.

4. Hsu YR, Yogasundaram H, Parajuli N, et al. MELAS syndrome and cardiomyopathy: linking mitochondrial function to heart failure pathogenesis. Heart Fail Rev 2016; 21: 103-16.

5. Koç F, Özeren A, Sarıca Y, et al. Genç inme nedeni olarak MELAS sendromu. Türk Serebrovasküler Hastalıklar Dergisi. 2004; 10: 135-8.
6. Cheldi A, Ronchi D, Bordoni A, et al. POLG1 mutations and stroke like episodes: a distinct clinical entity rather than an atypical MELAS syndrome. BMC Neurol 2013; 13: 8.

7. Kaufmann P, Engelstad K, Wei Y, et al. Natural history of MELAS associated with mitochondrial DNA m.3243A>G genotype. Neurology 2011; 77: 1965-71.

8. Murakami H, Ono K. MELAS: Mitochondrial Encephalomyopathy, Lactic Acidosis and StrokeLike Episodes. Brain Nerve 2017; 69: 111-17.

9. Sinnecker T, Andelova M, Mayr M, et al. Diagnosis of adult-onset MELAS syndrome in a 63-year-old patient with suspected recurrent strokes - a case report. BMC Neurol 2019; 19: 91.

10. Hongo Y, Kaneko J, Suga H, et al. A cluster of disseminated small cortical lesions in MELAS: its distinctive clinical and neuroimaging features. J Neurol 2019:266: 1459- 72.

11. Thambisetty M, Newman NJ. Diagnosis and management of MELAS. Expert Rev Mol Diagn 2004; 4: 631-44.

12. Wang YX, Le WD. Progress in Diagnosing Mitochondrial Myopathy, Encephalopathy, Lactic Acidosis, and Stroke-like Episodes. Chin Med J (Engl) 2015; 128: 1820-5.

13. El-Hattab AW, Adesina AM, Jones J, Scaglia F. MELAS syndrome: Clinical manifestations, pathogenesis, and treatment options. Mol Genet Metab 2015; 116: 4-12. 